УДК 82.09

https://doi.org/10.33989/2524-2490.2020.33.228193

KATERYNA NIKOLENKO

ORCID 0000-0002-1299-8483

(Полтава) (Poltava)

Place of study: Poltava V.G. Korolenko National Pedagogical University

Country: Ukraine

Email: katharina.nikolenko@gmail.com

OLGA NIKOLENKO

ORCID 0000-0001-7374-7226

(Полтава) (Poltava)

Place of work: Poltava V.G. Korolenko National Pedagogical University

Country: Ukraine

Email: omnicolenko@gmail.com

\title{
CONTEMPORARY STRATEGIES OF STUDYING INTERTEXTUALITY
}

У статті розглянуто аспекти й складники поняття «інтертекстуальність», різні трактування теорії інтертекстуальності у працях $М$. Бахтіна, Ю. Кристевої, Р. Барта й інших видатних літературознавиів $i$ критиків XX ст., зокрема представників постструктуралізму. У щирокому значенні інтертекстуальність визначають як структуру відношень між текстами, щцо можуть включати в себе пряле ццитування, алюзї, ілітацію, пародію та несвідоме звернення до літературних та культурних джерел. Це поняття значною мірою стирає межі між текстами, перетворюючи їх, як зазначив Р. Барт, на «безмежну тканину зв'язків та асоціацій». Терлін «інтертекстуальність» був уведений франиузькою письменницеюо та літературознавицею Ю. Кристевою наприкінці 1960-х років. Поеднавии ідеї Ф. де Соссюра та М. Бахтіна, Ю. Кристева розробила засади теорії інтертекстуальності, запропонувавщи переосмислити загальноприйняті поняттял «впливів» автора та «джерел» тексту. Цю теорію розробляв також Р. Барт, який проголосив «смерть автора» й піљкреслив, що читач ніколи не зможе осягнути повний спектр можливих значень літературного тексту, оскільки інтертекстуальна сутність твору завжди відсилае читачів до нових відношень між текстами. Французький критик Ж. Женетт увів більи охопне поняттл «транстекстуальність» $i$ запропонував n'ять типів транстекстуальних відношень (інтертекстуальність, паратекстуальність, архітекстуальність, метатекстуальність, гіпертекстуальність). До теорії інтертекстуальності активно зверталися митиці епохи постмодернізму. Вона набула поширення не лише в літературі, але й в інших галузях мистеитва (кінематограф, архітектура, образотворче мистецтво тощо), оскільки наслідування відомих мистецьких шкіл $і$ стилів, прямі та непрялі звернення до різних пам'яток культури стали важливим прийомом і характерною ознакою постмодернізму. У статті зазначено, що теорія інтертекстуальності трансформуе усталене розуміння тексту як самодостатньої герметичної єдності: створення літературного твору завжди відбувається за безпосередньої участі інших текстів і творів мистецтва, різноманітних соцчіальних та історичних чинників. В інтерпретації художнього тексту ключову роль відіграе також читач, оскільки його життевий досвід, рівень начитаності й обізнаності з творами культури та мистеццтва впливае на реццепцฺію змісту та його нюанси, щзо будуть доступні читачеві у процесі сприйняття літературного твору.

Ключові слова: інтертекстуальність; Ю. Кристева; М. Бахтін; Р. Барт; «смерть автора»; Ж. Женетт; постструктуралізи; постмодернізм; "діалог культур»; читач; рецепція. 
In recent years, the theory of intertextuality, as it pertains to literary studies in particular and cultural studies in general, has obtained a higher degree of significance from the viewpoint of literary analysis and interpretation of literary texts. The following article aims to explore contemporary approaches and theories regarding intertextuality in relation to how this notion may be interpreted in its broad and narrow definitions, and also through the prism of reader reception and "dialogue of cultures."

Contrary to the preexisting paradigm of literary analysis, wherein the extraction of meaning from a literary text was viewed as a fairly straightforward, linear process (also widely known as determining the main "idea" of the text, or deciphering "the author's thought process"), the theory of intertextuality proposes to view the text as a dynamic site, bringing to the foreground relational processes and practices in the text as opposed to static structures and products. Therefore, in the broadest terms possible, intertextuality can be defined as a set of relations between texts, which can include direct quotations, allusions, literary conventions, imitation, parody and unconscious sources among others.

This idea has been explored in great depth by M. Bakhtin, J. Kristeva, R. Barthes and other prominent scholars and literary critics of the $20^{\text {th }}$ century, particularly from the viewpoint of poststructuralism. Intertextuality maintains that a text "cannot exist as a hermetic or self-sufficient whole, and so does not function as a closed system" (Worton and Still, 1991, p. 1). The author compiles the text by reading other texts and the text becomes available to the audience in a process of reading.

The very term "intertextuality", which is derived from the Latin intertexto ("to intermingle while weaving"), was originally coined by the French semiotician and philosopher Julia Kristeva in the late 1960s. In her essays such as "Word, Dialogue, and Novel," J. Kristeva suggested reconsidering the generally accepted notions of the author's "influences" and the text's "sources," by putting forward the idea that all signifying systems, from table settings to poems, are constituted by the manner in which they transform earlier signifying systems. A literary work, then, is not simply the product of a single author, but of its relationship to other texts and to the structures of language itself. "Any text," she argues, "is constructed of a mosaic of quotations; any text is the absorption and transformation of another." (Kristeva, 1980 , p.37) She further elaborates her point by highlighting the multitude of meanings that can be inferred from any given text, and underlining that "the writer's interlocutor [...] is the writer himself, but as reader of another text. The one who writes is the same one as the one who reads. Since his interlocutor is a text, he himself is no more than a text rereading itself. The dialogical structure, therefore, appears only in the light of the text elaborating itself as ambivalent in relation to another text" (Kristeva, 1980, p. 86-87).

If we take a closer look at the genesis of this theory, we will almost inevitable notice that the origins of intertextuality can be traced back to $20^{\text {th }}$-century linguistics. A major role in understanding intertextuality was played, in particular, by the Swiss linguist Ferdinand de Saussure, who established the relational nature of meaning and texts by emphasizing the systematic features of language. Another scholar who had a major influence on the theory of intertextuality was the Russian literary theorist and philosopher Mikhail Bakhtin.

In his book, "Cultural Transactions: Nature, Self, Society," Paul Hernadi points out that Bakhtin emphasized the relation between an author and his work, the work and its readers, and the relation of all three to the social and historical forces that surround them (Hernadi, 1995). Perhaps the most representational in terms of delineating this idea of "dialogical relations" between the writer, the recipients of their work, and the text itself is M. Bakhtin's study of F. Dostoevsky. The Russian scholar particularly highlighted the type of writing wherein the characters are endowed with individual voices, however the narrator/author does not interfere. In M. Bakhtin's view, it is closely connected with the genre of the novel, and stands in contrast to various monophonic genres such as the epic or the poem. In the long run, however, such thoughts do not remain restricted to the novel, and lead M. Bakhtin to highly visionary ideas regarding the nature of literature and human communication in general. 
Therefore, by combining Saussurean and Bakhtinian theories, J. Kristeva produced the first enunciation of intertextual theory. While discussing the implications that her work has had in the domains of literary theory and literary criticism, though, it is important to bear in mind that J. Kristeva's work was published during a transitional period, namely during a shift from structuralism to poststructuralism.

Structuralists analyzed texts of all kinds, from works of literature to aspects of everyday communication. These theorists based their analysis on semiology, which is the study of signs, a movement fathered by F. de Saussure. Poststructuralists, on the other hand, believed in the unstable nature of language and meaning, insisting that all texts have multiple meanings.

This transitional period is characterized by the replacement of objectivity, scientific rigour, and methodological stability by an emphasis on uncertainty, indeterminancy, incommunicability, subjectivity, desire, pleasure, and play. While structuralists believed that criticism is objective, poststructuralists would argue that criticism, like literature, tends to be inherently unstable. However, what the two theories had in common was the postmodern obsession with language and with the radical claim of the disappearance of the individual.

This idea was perhaps most radically expressed in the works of Roland Barthes, who proclaimed the "death of the author" and insisted that in a work of literature, "it is language which speaks, not the author" (Barthes, 1977, p. 143). According to the French theorist, works of fiction are merely palimpsests and as such are devoid of any "single 'theological' meaning (the 'message' of the Author-God)" (Barthes, 1977, p. 146). He believed that the literary meaning can never be fully grasped by the reader, because the intertextual nature of literary works always leads readers on to new textual relations. Consequently, the key to deciphering the meaning of a given text will not be found in its "origin," but rather in its "destination": "...the birth of the reader must be at the cost of the death of the Author" (Barthes, 1977, p.148).

In "Theory of the Text", he writes: "Any text is a new tissue of past citations. Bits of code, formulae, rhythmic models, fragments of social languages, etc., pass into the text and are redistributed within it, for there is always language before and around the text. Intertextuality, the condition of any text whatsoever, cannot, of course, be reduced to a problem of sources or influences; the intertext is a general field of anonymous formulae whose origin can scarcely ever be located; of unconscious or automatic quotations, given without quotation marks" (Barthes, 1981, p.39). Thus, according to R. Barthes, writing is always an iteration which is also a re-iteration, a re-writing which bears traces and shadows of various other texts, both in a knowing and unknowing manner. He further describes literature as a territory "where all identity is lost, beginning with the very identity of the body that writes". The death of the author marks the birth of literature, defined, precisely, as "the invention of this voice, to which we cannot assign a specific origin."

In the context of this discussion, it is important to note that intertextual connections can be formed not only by referencing various works of literature or art, but also by social and historical determinants. Moreover, intertextuality usually involves assumptions regarding the reader, the situation being referred to, and its context. The reader's own previous readings, experiences and position within the cultural formation also form crucial connections and open new ways for interpreting literary works.

The French literary critic Gerard Genette took the idea of M. Bakhtin and J. Kristeva's concept of intertextuality - that texts are not the original product of one author one step further. In one of his most influential works, entitled "Palimpsests: Literature in the Second Degree", he proposes and defines 'transtextuality' as a more comprehensive term determining "all that sets the text in a relationship, whether obvious or concealed, with other texts." (Genette, 1997, p. 1) In other words, G. Genette's theory of transtextuality describes the numerous ways a later text prompts readers to read or remember an earlier one. He puts forward five types of transtextual relations. 
Intertextuality. As far as the original idea of intertextuality is concerned, in G. Genette's interpretation is becomes reduced to the "co-presence of two or more texts" in the form of quotation, plagiarism, and allusion. In this way, a more practical relationship between specific linguistic and literary elements of individual texts is established.

Paratextuality. Paratextuality refers to all other messages and commentaries which surround the text and may affect its interpretation. The paratext has a more pragmatic role; it guides the readers to consider the context of the document - to understand when the text was published, who published it, and for what purpose, and how the text should or should not be read. It can be categorized as peritext and epitext.

The peritext includes elements such as titles, chapter titles, captions and notes. It also involves dedications, illustrations, epigraphs and prefaces. For example, in R. Heinlein's "Job: A Comedy of Justice," the epigraph to Chapter 1 is a Biblical quotation: "When thou walkest through the fire, thou shalt not be burned" (Isaiah 43:2). (Heinlein, 1985, p. 1)

The epitext consists of elements beyond the text such as interviews, public relation announcements, reviews and other authorial and editorial discourse.

Metatextuality. Metatextuality is the relation between one text and another, wherein the commented text is clearly and obviously cited, referenced, or mentioned. In this case, G. Genette proposes that a text can be linked to another without it being named or cited and instead through the use of an implied understandable reference.

For example, when the phrase "Manuscripts don't burn" appears in the text, the reader may quite correctly infer that $\mathrm{M}$. Bulgakov's famous novel "The Master and Margarita" is being referenced, although the author's name and/or the title of his work may or may not be stated explicitly. The same applies to other recognizable quotations which have now become just as relevant in public discourse as proverbs and adages of old times: e.g. "Everything was in confusion in the Oblonsky's house" (L. Tolstoy, "Anna Karenina"), or "All animals are equal, but some animals are more equal than others" (George Orwell, "Animal Farm").

A more subtle instance of metatextuality may be observed in G.B. Shaw's play "Candida," wherein the legend about Tristan and Isolde is referenced indirectly, through the use of a recognizable metaphor (a sword laid between two lovers symbolizing fidelity and chastity): "If I were a hero of old, I should have laid my drawn sword between us. If Morell had come in he would have thought you had taken up the poker because there was no sword between us" (Shaw, 1981, p. 44).

Metatextuality also applies to explicit or implicit critical commentary of one text on another text. So it may be a book of commentary on a literary text, e.g. "Problems of Dostoevsky's Poetics" by M. Bakhtin or "Pygmalion: Shaw's Spin on Myth and Cinderella" by Ch. Berst.

Architextuality. Architextuality refers to the text being positioned directly or indirectly into a generic category due to its title, even before the reader has received or read the work. In other words, the title of a piece of work or a particular word in a title may alter the reader's expectations about the text.

Hypertextuality. Hypertextuality refers to the relationship between two texts: The hypertext, and another text which G. Genette refers to as the hypotext. The hypertext transforms, modifies, elaborates, or extends the hypotext - but does not keep to the style "of the commentary" of the original text. For instance, "The Aeneid" and "Ulysses" are, in different degrees, two hypertexts of the same hypotext, "The Odyssey". Hypertextuality highlights all the ways one text can change another. Per G. Genette, all texts are basically hypertextual, but sometimes it is difficult to recognise the existence of a hypotext.

However, despite the fact that this classification aims to be incredibly detailed and precise, the five categories established by G. Genette will sometimes overlap when it comes to practice. Researcher Maria Alfaro pointed out that the paratext may also contribute to determining the generic quality of the text, thus merging with architextuality. She also underlined the fact that notions like 'intertextuality' and 'hypertextuality' may 
often be hard to differentiate between, and so (in a lot of cases) it might make more sense to use an umbrella term like 'intertextuality' (Alfaro, 1996).

Among contemporary scholars, the prominent American literary critic and Professor of Humanities at Yale University Harold Bloom had been the most consistent in his dedication to intertextual theory and practice. Among his scholarly interests, H. Bloom's work on nineteenth-century poetry and Romantic poetry in particular deserves a special place not in the least because it can help us better understand his views on intertextuality.

For the American scholar, poets employ the central figures of previous poetry but they transform, redirect, reinterpret those already written figures in new ways and hence create an impression that their poetry is not influenced by, and not therefore a misreading of, the precursor poem. Modern poetry, according to H. Bloom, is dominated by various kinds of figurative misreadings, and he even developed an expanding 'map of misreading' in his work of the 1970s.

Intertextuality is for Bloom a product of the 'anxiety of influence'. He is concerned with motivation, with the reasons why people write in a culture in which everything seems to have already been written, and written in better ways - and in which, as a consequence, there is no way of ever producing writing that is representational of the world, of producing writing that does anything more than rewrite what has already been written.

There is, however, a growing movement to reexamine and rethink the current interpretations of literary works. According to an influential feminist critic Elaine Showalter, one of the important critical approaches of today is the feminist study of women's writing, including readings of women's texts and analyses of the intertextual relations both between women writers (a female literary tradition), and between women and men (Showalter, 1986). Nowadays there are growing attempts to shift the focus from white, patriarchal, European-centric, male-dominated culture (in terms of forming the current literary landscape as well as in terms of critical reception) to a wider range of different cultures and perspectives, including previously overlooked groups, like women, people of color, indigenous communities etc.

A recent feminist theorist, Monika Kaup, attempts to confront these problems by adding a poststructuralist approach. In her opinion, intertextuality may be defined as "an open exchange between the domain of literature and a 'universe' of intersecting scientific, cultural, ideological and literary discourses or 'voices', and, conversely, the potential rhythm, merging and overlay of those heterogeneous voices within what we usually regard as a 'single literary text'." (Kaup, 1993, p. 12-13).

It is also important to highlight that intertextuality, as a term, is not restricted to discussions of the literary arts. Films, musical pieces, architecture, paintings communicate with each other constantly, just like literary texts, and the abundance of explicit and implicit references between various types of art offers near infinite opportunities for artistic expression and communication.

In terms of visual arts, for example, Wendy Steiner underlines that "It is only by viewing paintings in light of other paintings or works of literature, music, and so forth that the 'missing' semiotic power of pictorial art can be augmented - which is to say that the power is not missing at all, but merely absent in the conventional account of the structure of the art." (Steiner, 1985, p. 58)

W. Steiner shows that painters will often 'quote' culturally recognizable styles of earlier schools or individual artists. Their ability to parody styles and gestures suggests a profound intertextual level to the pictorial arts. Modernist \& postmodernist painting, with its tendency towards collage, the mixing of different media, and the use of 'found material', might extend possibilities for intertextual expression. Some notable examples to illustrate this point would include the work of Cy Twombly (who was deeply influenced by Modern European art, particularly twentieth century European painting and Italian tradition) and Jean-Michel Basquiat (who combined recognizable Christian imagery and motifs with elements of African art, and brought into focus the realities of life in the USA of the 1970s and 1980s). 
Intertextuality has thrived in the era of Postmodernism. For architect and theorist Charles Jencks, the Postmodern age is "a time of incessant choosing ... an era when no orthodoxy can be adopted without self-consciousness and irony, because all traditions seem to have some validity" (Jencks, 1989, p. 7).

According to Ch. Jencks, "Post-Modernism is fundamentally the eclectic mixture of any tradition with that of the immediate past: it is both the continuation of Modernism and its transcendence. Its best works are characteristically double-coded and ironic [...]. Its hybrid style is opposed to the minimalism of Late-Modern ideology and all revivals which are based on an exclusive dogma or taste" (Jencks, 1989, p. 7).

To summarize, the concept of intertextuality dramatically blurs the outlines of texts, making them, in R. Barthes's words, an "illimitable tissue of connections and associations." (Barthes, 1981, p. 39) Intertextuality subverts the concept of the text as self-sufficient, hermetic totality. Instead, it emphasizes the fact that all literary production takes place in the presence of other texts, works of culture, and various social and historical factors. The reader also plays a crucial role in interpreting the text, because the reader's previous experiences, their cultural and educational background will inevitably influence the scope of meanings that the reader is able to extract from the text.

\section{REFERENCES}

Alfaro, M. (1996). Intertextuality: Origins and Development of the Concept. Atlantis, 18(1/2), 268285. Retrieved from http://www.jstor.org/stable/41054827

Allen, G. (1994). Harold Bloom: a poetics of conflict. Hemel Hempstead: Harvester Wheatsheaf.

Bakhtin, M. M. (1963). Problems of Dostoevsky's Poetics. Moscow: Khudozhestvennaja literatura [in Russian].

Barthes, R. (1977). The Death of the Author. Image, Music, Text. Trans. S. Heath. London: Fontana, 142-148.

Barthes, R. (1981). Theory of the Text. Untying the Text: A Post-Structuralist Reader. Ed. Robert Young. London: Routledge and Kegan Paul, 31-47.

Genette, G. (1997). Palimpsests: Literature in the Second Degree. Trans. Channa Newman and Claude Doubinsky. Lincoln: University of Nebraska Press.

Heinlein, R. (1985). Job: A Comedy of Justice. New York: Del Rey.

Hernadi, P. (1995). Cultural Transactions: Nature, Self, Society. New York: Cornell University Press. Jencks, Ch. (1989). What is Post-Modernism? New York: Academy.

Kaup, M. (1993). Mad Intertextuality: madness in twentieth-century women's writing. Trier: WVT.

Kristeva, J. (1980). Word, Dialogue, and Novel. Desire in Language: A Semiotic Approach to Literature and Art. Ed. Leon S. Roudiez. Trans. Thomas Gora et al. New York: Columbia University.

Shaw, G. B. (1981). Selected Plays. New York: Dodd, Mead and Company.

Showalter, E. (Ed.). (1986). The New Feminist Criticism: essays on women, literature and theory. London: Virago.

Steiner, W. (1985). Intertextuality in Painting. American Journal of Semiotics, 3 (4), 57-67.

Worton, M., \& Still, J. (1990). Intertextuality: Theories and Practices. Manchester: Manchester University Press.

Gibbs A.M. (1990). Candida. In Gibbs A.M. (Ed.) Shaw. Interviews and Recollections Series. Palgrave Macmillan, London.

\section{KATERYNA NIKOLENKO, OLGA NIKOLENKO}

\section{CONTEMPORARY STRATEGIES OF STUDYING INTERTEXTUALITY}

The article explores the definition and the essence of intertextual theory as it is interpreted by M. Bakhtin, J. Kristeva, R. Barthes and other prominent scholars and literary critics of the $20^{\text {th }}$ century, particularly from the viewpoint of poststructuralism. In the broadest terms possible, intertextuality can be defined as a set of relations between texts, which can include direct quotations, allusions, literary conventions, imitation, parody and unconscious sources among others. This concept dramatically blurs the outlines of texts, making them, in R. Barthes's words, an "illimitable tissue of connections and associations." The term itself was originally coined by the French semiotician and philosopher Julia Kristeva in the late 1960s. By combining Saussurean and Bakhtinian theories, J. Kristeva produced the first enunciation of intertextual theory, wherein she essentially 
suggested reconsidering the widely accepted notions of the author's "influences" and the text's "sources". This theory was further developed by R. Barthes, who proclaimed the "death of the author" and insisted that the literary meaning can never be fully grasped by the reader, because the intertextual nature of literary works always leads readers on to new textual relations. In turn, French critic G. Genette introduced the notion of 'transtextuality' as a more comprehensive term, and put forward five types of transtextual relations (intertextuality, paratextuality, metatextuality, architextuality, hypertextuality). This theory has also become widely popular in the era of postmodernism, not just in relation to literary works, but also in other domains (cinematography, architecture, pictorial arts etc), as imitation of well-known artistic styles, direct and indirect references to various works of culture have become a salient feature of postmodern art. In general, it should be emphasized that intertextuality subverts the concept of the text as self-sufficient, hermetic totality. Instead, it emphasizes the fact that all literary production takes place in the presence of other texts, works of culture, and various social and historical factors. The reader also plays a crucial role in interpreting the text, because the reader's previous experiences, their cultural and educational background will inevitably influence the scope of meanings that the reader is able to extract from the text.

Key words: intertextuality, J. Kristeva, M. Bakhtin, R. Barthes, "death of the author", G. Genette, poststructuralism, postmodernism, "dialogue of cultures", reader, reception.

Отримано 23.11.2020 p. 